\title{
Efektifitas Intervensi Self-Management pada Pasien Stroke
}

\author{
Irmina Ika Yuniarti ${ }^{1 *}$, I Made Kariasa ${ }^{2}$, Agung Waluyo ${ }^{3}$ \\ ${ }^{1}$ Magister Keperawatan, Fakultas Ilmu Keperawatan, Universitas Indonesia \\ ${ }^{2,3}$ Fakultas Ilmu Keperawatan, Universitas Indonesia \\ *Email: ika.irmina@gmail.com
}

\begin{abstract}
Background: Stroke is a neurological change that occurs quickly caused by disruption of blood supply to parts of the brain. Stroke has a complex impact which includes bio-psycho-social and spiritual. Various complexities of problems encountered in stroke patients so that self-management is needed as a form of adaptation to new conditions after stroke. Self-management interventions are useful for improving selfmanagement skills and behavior in stroke patients. Purpose this study is to analize effectiveness of selfmanagement interventions in stroke patients. Methods: Narrative literature review, research analyzes published in the online databases of ProQuest, Google scholar and Scopus. The study was selected using the criteria and keywords for the 2015-2019 period. Seven studies were analyzed using the literature review process. Results: To improve self-management stroke patients, self-management interventions are needed. Self-management interventions can be applied in hospitals when post acute patients are hospitalized, preparation for discharge, return and after discharge home and can be combined with rehabilitation programs in the community. Self-management interventions can improve self-efficacy, selfmanagement behavior, activity daily living (ADL) ability, decreased re-hospitalisation and patient readiness to return to the community. Conclusion: Self-management interventions can be applied in Indonesia, with a note that among others prepared human resources, costs, supporting facilities and policies from the manager.
\end{abstract}

Keyword: self-management, intervensi self-management, stroke

\section{PENDAHULUAN}

Stroke didefinisikan World Health Organization (WHO) sebagai perkembangan yang cepat dari tanda klinis dan gejala gangguan neurologi fokal atau global yang terjadi lebih dari 24 jam. Stoke dapat menyebabkan kematian tanpa ditemukan penyebab lain, selain penyebab vaskuler (Donkor, 2018). Stroke merupakan penyebab kematian ke 5 di Amerika disamping disebabkan oleh penyakit jantung, kanker, gagal ginjal dan kecelakaan (Mozaffarian et al., 2016). Stroke merupakan istilah yang digunakan untuk menggambarkan perubahan neurologis yang disebabkan oleh adanya gangguan suplai darah ke bagian dari otak.

Terapat dua jenis stroke yaitu iskemik dan hemoragik. Insiden stroke iskemik sekitar $83 \%$ dari seluruh kasus stroke, dan stroke hemoragik sebesar $17 \%$. Etiologi stroke meliputi thrombosis, embolisme, perdarahan atau hemoragik dan penyebab lain yaitu spasme arteri serebral yang disebabkan oleh infeksi, penurunan aliran darah ke otak dan kondisi hiperkoagulasi. Hiperkoagulasi yaitu terjadi penggumpalan yang berlebihan pada pembuluh darah (Black \& Hawks, 2014).

Meningkatnya angka harapan hidup, menyebabkan angka kejadian stroke di dunia menjadi meningkat dari tahun ke tahun. Peningkatan populasi usia lanjut berdampak pada prevalensi stroke yang meningkat. Berdasarkan laporan Riskesdas tahun 2018, didapatkan prevalensi stroke pada penduduk umur lebih dari atau sama dengan 15 tahun di Indonesia pada tahun 2013 yaitu 7 per 1000 penduduk dan pada tahun 2018 
meningkat menjadi 10.9 per 1000 penduduk. Berdasarkan hasil tersebut dapat disimpulkan bahwa terdapat peningkatan jumlah penderita stroke yang signifikan dari tahun 2013 sampai dengan tahun 2018 yaitu sebesar 3.9 per 1000 .

Stroke memiliki dampak yang bersifat kompleks meliputi bio-psikososial dan spiritual. Kompleksitas masalah yang ditemui pada pasien stroke, sehingga memerlukan self-management sebagai bentuk adaptasi pada kondisi baru setelah stroke. Intervensi self-management bermanfaat untuk meningkatkan ketrampilan dan perilaku self-management pada pasien stroke. Konsep selfmanagement pertama kali dikenalkan pada tahun 1976 oleh Creer dan kolega.

Self-management didefinisikan sebagai partisipasi aktif pasien pada pengobatan medis, dan diperkenalkan pertama kali, serta masuk ke dalam guideline perawatan pasien stroke di UK sekitar tahun 2009 (Pearce et al., 2015). Self management dikenalkan pada pasien stroke mulai dari fase akut, persiapan pemulangan dan pada saat pasien sudah keluar dari rumah sakit dan berada kembali dalam komunitas. Selfmanagement mampu memberikan peningkatan pada kualitas hidup, kemampuan aktifititas ADL, self-efficacy, menurunnya angka rehospitalisasi pada pasien stroke dan mereka mampu berintegrasi ke kehidupan sebelum sakit. Self-management sekarang secara luas digunakan untuk mendukung individu setelah stroke dalam membantu mereka mempelajari strategi untuk memanajemen perawatan sehari-hari yang dibutuhkan berhubungan dengan kondisi mereka (Wolf, Spiers, Doherty, \& Leary, 2017).

Self-management menurut Barlow et al (2002) di definisikan sebagai kemampuan individu dalam memanajemen gejala, pengobatan, perubahan fisik dan psikologi serta perubahan gaya hidup yang bersifat menetap dengan kondisi kronik (Fletcher, Kulnik, Demain, \& Jones, 2019). Pasien stroke memonitor dan memanajemen penyakit melalui tindakan dengan tujuan kesehatan secara proaktif untuk menurunkan efek suatu penyakit melalui pengobatan, serta mempertahankan, dan meningkatkan kesehatan (Guan, Wang, \& Lian, 2018). Self-management juga dapat memberikan alternatif penyelesaian bagi pasien stroke untuk meningkatkan pemulihan.

Intervensi self-management meliputi edukasi spesifik tentang stroke dan efeknya tetapi berfokus pada pelatihan ketrampilan untuk meningkatkan semangat untuk aktif pada manajemen mereka. Ketrampilan tersebut antara lain kemampuan untuk memecahkan masalah, menentukan tujuan, membuat keputusan dan pemecahan masalah (Ce, Ja, Mn, \& S1, 2016). Sebagai upaya untuk mencapai keberhasilan self management dibutuhkan sebuah strategi antara lain intervensi untuk memberdayakan pasien dalam program pengobatan atau rehabilitasi.

Pemberdayaan pasien akan meningkatkan partisipasi pasien pada program. Meningkatnya partisipasi pasien secara tidak langsung akan meningkatkan self- efficacy, perilaku self management dan pemulihan fungsi serta menurunkan rehospitalisasi. Pendekatan selfmanagement dapat meningkatkan kepercayaan diri dan kemampuan memanajemen kehidupan kembali ke komunitas dan partisipasi setelah peralihan ke komunitas. Tujuan dari ini adalah untuk menganalisis intervensi selfmanagement pada pasien stroke. 


\section{METODE PENELITIAN}

Desain menggunakan naratif literatur review. Penelusuran dilakukan dengan mencari hasil penelitian yang diterbitkan pada basis data online, proquest, google scholar dan scopus. Permulaan pencarian menggunakan kata kunci self-management, self-management intervention dan stroke untuk menggabungkan kata kunci "AND" dan "OR" diterapkan dalam pencarian. Berdasarkan penelusuran dengan memasukkan kata kunci didapatkan hasil: basis data scopus 489 artikel, proquest 36.767 artikel, google scholar 19.400 artikel. Seleksi penelitian dilakukan dengan menyaring judul untuk pengecualian penelitian yang tidak relevan menghasilkan 223 artikel. Hasil temuan setelah menghapus duplikasi di dapatkan sebanyak 105 artikel.

Hasil temuan sesuai dengan kriteria inklusi dan eksklusi didapatkan 49 artikel. Eksklusi dengan alas an tertentu sebanyak
28 artikel. Selanjutnya dilakukan proses skrining dan pengkajian terhadap kelayakan terdapat 14 artikel yang dikeluarkan. Tujuh penelitian dilakukan analisa menggunakan proses literature review.

Kriteria inklusi meliputi artikel berbahasa Inggris diterbitkan antara 20152019, full teks, penelitian kuantitatif dan kualitatif, desain penelitian meliputi RCT dan quasi eksperimen, topik mengenai intervensi self-management pada pasien stroke. Sedangkan kriteria eksklusi adalah penelitian yang diterbitkan sebelum tahun 2015, berbahasa Indonesia, artikel tidak full teks, tidak memiliki struktur artikel yang lengkap, artikel merupakan literature review dan memiliki desain cross sectional.

\section{HASIL PENELITIAN}

Peneliti menganalisis 7 artikel yang dipilih sesuai dengan tabel 1 berikut:

Tabel 1. Tabel Review Artikel

\begin{tabular}{|c|c|c|c|c|c|}
\hline No & Judul & Author & Metodologi & Hasil & Kesimpulan \& Saran \\
\hline 1. & $\begin{array}{l}\text { Feasibiliy } \\
\text { studi of an } \\
\text { integrated } \\
\text { stroke self- } \\
\text { management } \\
\text { programme: a } \\
\text { cluster- } \\
\text { randomised } \\
\text { controlled } \\
\text { trial } \\
(2015)\end{array}$ & $\begin{array}{l}\text { Jones et } \\
\text { al }\end{array}$ & $\begin{array}{l}\text { Metode: } \\
\text { Cluster- } \\
\text { randomised } \\
\text { controlled trial } \\
\text { Sampel: } 78 \\
\text { pasien dengan } \\
\text { diagnosa stroke } \\
\text { yang } \\
\text { memerlukan } \\
\text { rehabilitasi } \\
\text { berbasis } \\
\text { komunitas. }\end{array}$ & $\begin{array}{l}\text { Hasil studi } \\
\text { memperlihatkan } \\
\text { tidak terdapat } \\
\text { perbedaan yang } \\
\text { signifikan antara } \\
\text { grup perlakuan } \\
\text { tetapi pengukuran } \\
\text { dari kapasitas } \\
\text { fungsional dan } \\
\text { self efficacy } \\
\text { memperlihatkan } \\
\text { respon pada grup } \\
\text { intervensi }\end{array}$ & $\begin{array}{l}\text { The Bridges program } \\
\text { self management layak } \\
\text { untuk digabungkan } \\
\text { pada program self } \\
\text { management stroke } \\
\text { pada rehabilitasi } \\
\text { berbasis komunitas. }\end{array}$ \\
\hline 2. & $\begin{array}{l}\text { Examining a } \\
\text { participation- } \\
\text { focused stroke } \\
\text { self } \\
\text { management } \\
\text { intervention in } \\
\text { a day }\end{array}$ & Lee et al & $\begin{array}{l}\text { Metode :mixed- } \\
\text { method non- } \\
\text { randomized } \\
\text { quasi } \\
\text { eksperimen } \\
\text { Sampel : } 17 \\
\text { partisipan }\end{array}$ & $\begin{array}{l}\text { Secara } \\
\text { keseluruhan hasil } \\
\text { memperlihatkan } \\
\text { kecenderungan } \\
\text { perubahan positif } \\
\text { yang besar pada } \\
\text { grup intervensi }\end{array}$ & 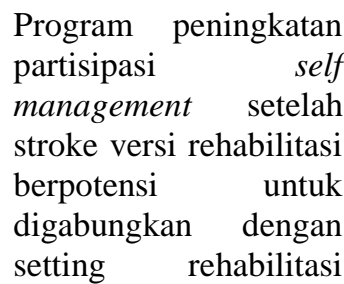 \\
\hline
\end{tabular}




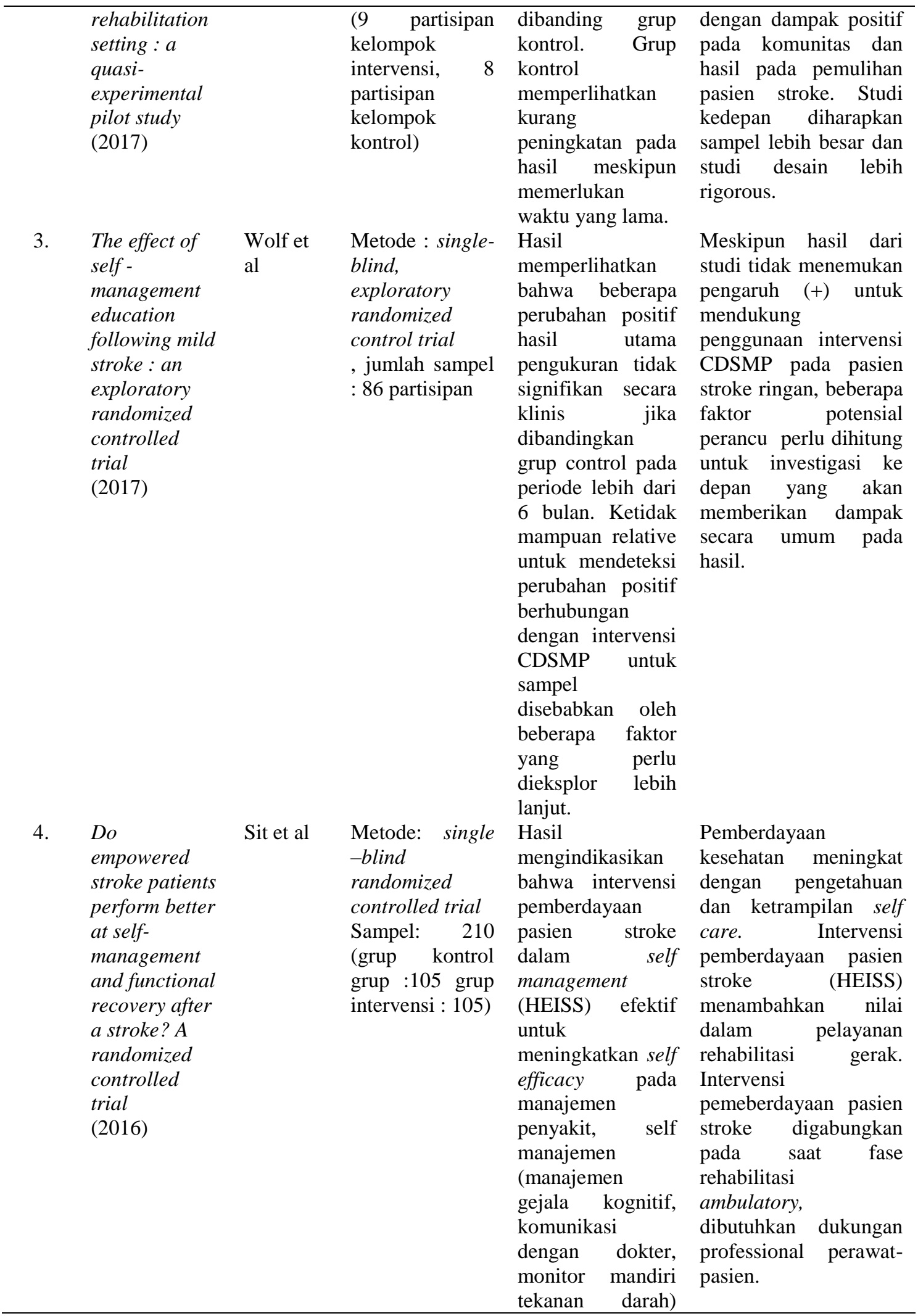




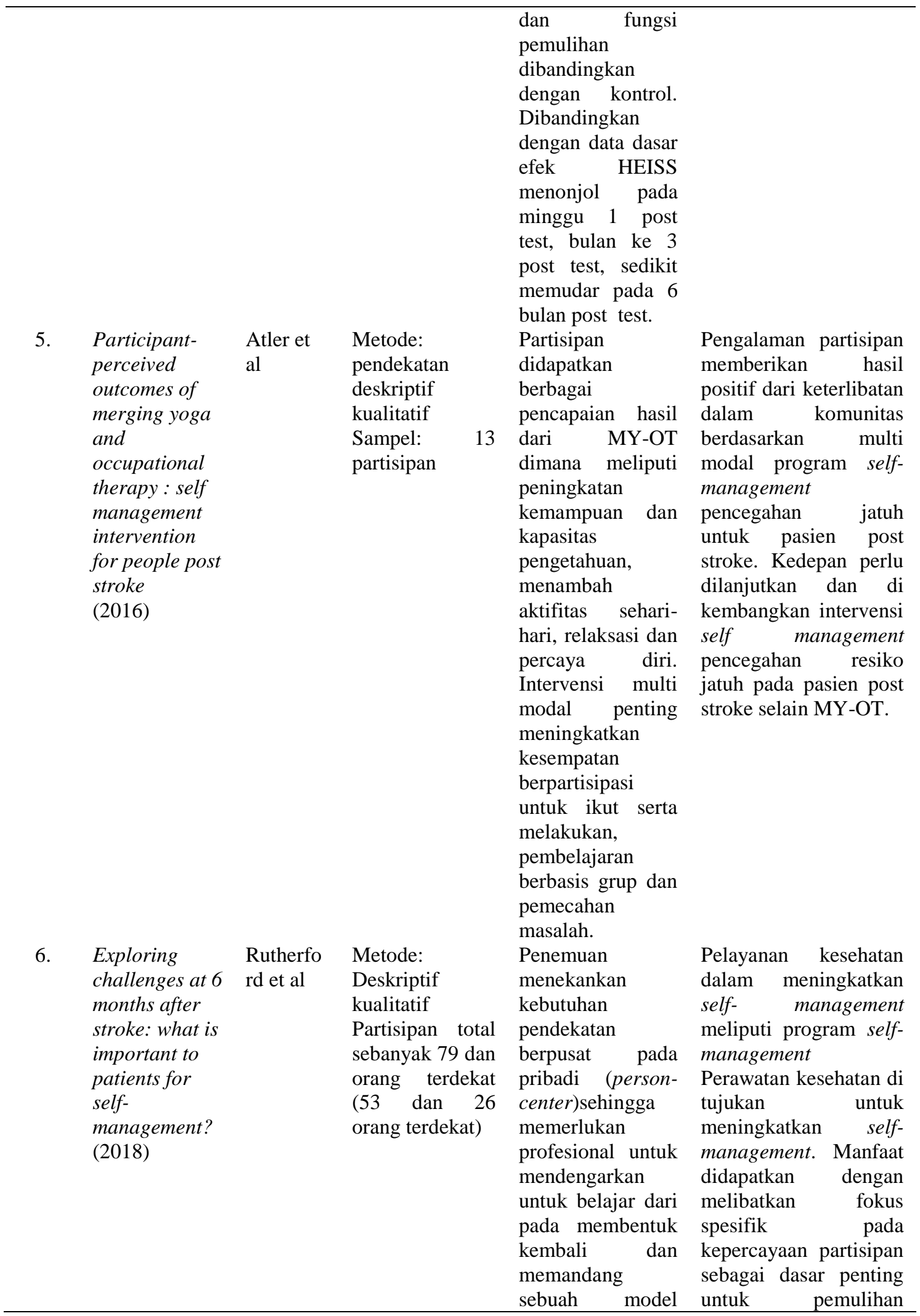




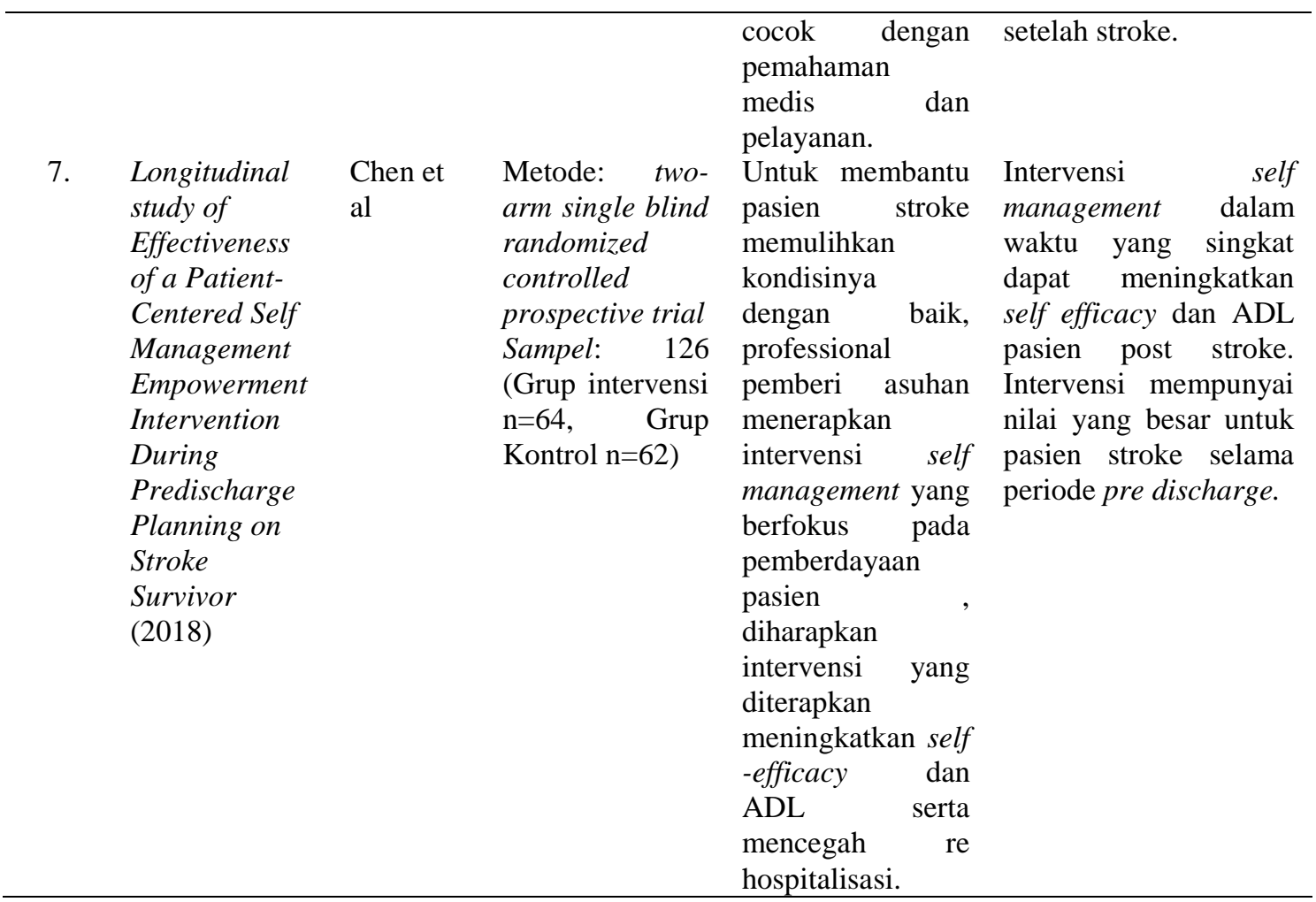

Intervensi self-management antara lain intervensi pemberdayaan kesehatan pada self-management pasien stroke. Sit et al (2016) menyampaikan konsep HEISS (Health Empowerment Intervention for Stroke Self-Management) yang memiliki arti yaitu sebuah intervensi pada pasien stroke yang bertujuan untuk memberdayakan pasien stroke dengan pengetahuan dan ketrampilan serta kepercayaan diri untuk meningkatkan self-management. Intervensi diharapkan dapat mempengaruhi self-efficacy dalam memanajemen penyakit, meningkatkan perilaku self-management dan meningkatkan kemampuan fungsional pasien stroke. Dalam pelaksanaannya HEISS digabungkan dengan pelayanan rehabilitasi post stroke.

Intervensi terdiri dari 2 bagian yaitu bagian 1 sekitar 6 minggu sesi grup kecil dari minggu ke 3 sampai minggu ke 8 yang bersamaan dengan jadwal rehabilitasi di rawat jalan. Peserta di bagi menjadi kelompok yang terdiri dari 4-6 peserta, dengan fasilitator perawat untuk menetapkan tujuan secara individu dan perencanaan tindakan serta kegiatan selfefficacy untuk mengembangkan ketrampilan self-management. Penetapan tujuan pribadi dan rencana tindakan disepakati bersama pada saat penyelesaian kelompok sesi 6 minggu. Peserta juga diberikan buku kerja self-management stroke sebagai petunjuk pelaksanaan di rumah.

Bagian 2 meliputi implementasi di rumah setelah pulang dari rumah sakit. Selama minggu ke 9 sampai 13 setiap 2 minggu sekali follow up melalui telepon. Perawat fasilitator memberikan semangat, umpan balik langkah self-management secara berurutan dan strategi pemecahan masalah untuk memperkuat rasa percaya 
diri dan motivasi. HEISS efektif meningkatkan self-management menonjol pada minggu pertama post test, bulan ke tiga post test, sedikit berkurang pada enam bulan post test. Analisa terkait hasil yang didapatkan sedikit berkurang pada enam bulan post test adalah adanya pemulihan secara bertahap pada mobilitas dan meningkatnya rasa percaya diri sebagai adaptasi terhadap pemulihan. Disamping itu berkurangnya kontak dengan petugas kesehatan dan tidak ada peningkatan penguatan enam bulan setelah intervensi.

HEISS muncul dilatarbelakangi bahwa self-management setelah stroke merupakan sebuah tantangan. Kondisi tersebut disebabkan keanekaragaman kebutuhan perawatan dan disabilitas komplek, menghalangi pasien untuk berpartisipasi dalam perawatan. Sejalan dengan Sit et al (2016), terdapat penelitian lain tentang intervensi pemberdayaan self-management yang berpusat pada pasien. Intervensi disebut dengan patient-centered self-management empowerment intervention disingkat dengan PCSMEI. Penelitian dilakukan oleh Chen et al (2018). Tujuan dari penelitian ini adalah mengkaji keefektifan program PCSMEI pada self efficacy, aktifities of daily living (ADL) dan rehospitalisasi dari pasien stroke yang terkena serangan pertama kali. Intervensi dimulai sejak pasien masih di rawat yaitu dengan melakukan pengkajian yang berpusat pada pasien, edukasi selfmanagement terdiri dari edukasi individual dan kelompok kecil.

Sesi individual pada minggu pertama diadakan hari ke tiga sampai ke tujuh setelah kondisi pasien stabil untuk mentransfer pengetahuan dan ketrampilan self-management. Sesi grup kecil pada minggu kedua tujuannya adalah meningkatkan partisipasi untuk berkomunikasi dengan yang lain, sesi selama 60 menit satu grup terdiri dari 8 partisipan. Pada periode persiapan pulang untuk meningkatkan kesiapan pemulangan. Diskusi antara perawat, pasien dan keluarga sebagai informal care giver di ruang rawat inap. Diskusi meliputi pengkajian sebelum pemulangan, rehabilitasi dan penentuan tujuan selfmanagement.

Periode setelah pemulangan tujuannya adalah mengkaji ketrampilan dan tingkah laku self-management. Sesi meliputi empat kali telepon setiap minggu selama 20-30 menit setiap sesi. Kelompok kontrol juga mendapatkan nomer telepon yang sama untuk pembicaraan sosial secara umum dengan tujuan untuk memberikan efek keseimbangan psikologis dari kontak kontak profesional. Tiga penelitian serupa lain dilakukan juga oleh (Wolf et al., 2017). Penelitian bertujuan mengkaji intervensi selfmanagement pada pasien dengan stroke ringan menggunakan the chronic disease self-management program (CDSMP). CDSMP merupakan program pendidikan berdasarkan konsep self-management pada penyakit kronis. CDSMP terdiri dari enam sesi yang difokuskan pada tiga tujuan utama yaitu manajemen penyakit, manajemen peran dan manajemen emosional. Hasil penelitian menemukan tidak adanya pengaruh positif yang mendukung penggunaan intervensi selfmanagement CDSMP pada pasien stroke ringan. Beberapa faktor perancu mungkin perlu diperhatikan lebih lanjut dalam penelitian masa depan yang akan memberikan dampak secara umum pada hasil. Faktor tersebut meliputi jumlah sampel yang kecil, heterogenitas dalam sampel dan perlu menggunakan instrumen 
tambahan untuk mengevaluasi perilaku kesehatan.

Lee, Fischer, Zera, Robertson, \& Hammel (2017), mengevaluasi kelayakan dan keefektifan intervensi improving participation after stroke selfmanagement program-rehab version (IPASS-R). Intervensi self-management dalam pengaturan rehabilitasi program untuk meningkatkan partisipasi setelah stroke versi rehabilitasi. Intervensi ini berpotensi untuk digabungkan dengan rehabilitasi rawat jalan. Intervensi memberikan dampak positif peningkatan integrasi di masyarakat serta hasil pada pemulihan pasien stroke.

IPASS-R terdiri dari 6 sesi selama 90 menit. Kelompok terdiri dari 3-4 anggota yang dipimpin oleh seorang fisioterapi (okupasi terapis) dan peer fasilitator. Kedua fasilitator adalah CDSMP yang bersertifikat dan sebelumnya telah mempunyai pengalaman di program IPASS. Buku pedoman disediakan untuk membantu peserta secara visual sehingga mengikuti konten dalam setiap sesi. Hasil penelitian menunjukkan program IPASS-R memiliki potensi untuk diberikan pada rehabilitasi rawat jalan dan memiliki dampak positif pada pemulihan dan integrasi pasien pasca stroke kembali ke masyarakat.

Jones (2016) mengintegrasikan intervensi self-management pada rehabilitasi stroke berbasis komunitas. Intervensi self-management juga dapat digabungkan pada program rehabilitasi di komunitas menggunakan prinsip utama yaitu pemecahan masalah, refleksi, penentuan tujuan, mengkaji sumber daya, penemuan diri, aktivitas dan pengetahuan. Intervensi self-management pada pasien stroke dapat secara luas digunakan baik pada seting pasien rawat inap ataupun sudah dipulangkan dan program rehabilitasi di komunitas. Penyediaan rehabilitasi stroke rutin dalam 2 cara utama yaitu: satu persatu dari sesi rehabilitasi menggunakan tujuh prinsip yang diintegrasikan ke dalam setiap sesi terapi untuk mendukung kegiatan selfmanagement, dan buku kerja stroke yang mencakup gambaran, kegiatan, usulan dan solusi dari pasien stroke lainnya serta merefleksikan tujuan dan kemajuan.

Beberapa penelitian kualitatif mengenai intervensi untuk meningkatkan self-management pada pasien stroke, antara lain penelitian yang dilakukan oleh Atler, Van Puymbroeck, Portz, \& Schmid (2017). Hasil penelitiannya yaitu program self-management pada pasien stroke mencakup berbagai pembahasan termasuk diantaranya manajemen resiko jatuh. Penelitian ini bertujuan untuk mengeksplorasi perubahan yang dirasakan pasien stroke dalam kemampuan pada program merging yoga-ocupational therapy (MY-OT) dalam hubungannya dengan upaya pencegahan jatuh pasien post stroke. Penelitian ini melaporkan bukti efektifitas intervensi selfmanagement dengan memberdayakan pasien stroke.

Program MY-OT dilakukan 2 kali seminggu setiap sesi selama 2 jam. Jam pertama diskusi kelompok yang dipimpin oleh terapis okupasi. Pasien menganalisa risiko jatuh dan mengembangkan strategi pencegahan meliputi perilaku, kegiatan, efek stroke dan lingkungan. Jam kedua instruktur yoga mengajarkan program yoga yang terdiri dari postur yoga pada posisi duduk, berdiri, telentang, latihan pernafasan dan meditasi. Pasien diberikan alat bantu untuk melaksanakan program dirumah misalnya rekaman relaksasi. 
Penelitian kualitatif lain mengenai pengaruh intervensi self-management dilakukan oleh Rutherford, Hocking, Theadom, \& McPherson (2018).Tujuan dari penelitian ini adalah untuk mengeksplorasi perhatian dan pengaruh self-management pasien stroke dalam memanajemen enam bulan post stroke. Temuan menunjukkan bahwa perawatan kesehatan yang ditargetkan untuk meningkatkan self-management termasuk program self-management terletak pada keyakinan pasien sebagai landasan penting untuk pemulihan setelah stroke. Program self-management harus didukung oleh tehnik perubahan perilaku spesifik yang mempengaruhi sikap dan respon pasien. Program dirancang untuk meningkatkan ketrampilan, kepercayaan diri dan motivasi yang memungkinkan pasien mengelola kondisi secara lebih efektif dan mandiri.

\section{PEMBAHASAN}

Intervensi

self-management diharapkan dapat memfasilitasi pasien stroke beradaptasi dengan perubahan fisik, kognitif, emosional dan peran yang terjadi akibat stroke. Program self-management sangat diperlukan karena merupakan bekal pada pasien stroke dan keluarganya sebagai informal caregiver untuk mempersiapkan dalam memanajemen dirinya dan mengelola penyakit. Intervensi self-management difokuskan pada pemberdayaan pasien. Pemberdayaan merupakan proses memfasilitasi pasien pada keputusan mengenai kesehatan dan perawatan yang di wujudkan dalam partisipasi dan perilaku self-management.

Pemberdayaan mendorong pasien stroke memaksimalkan potensi yang dimiliki untuk mengelola kesehatan dan kehidupan sehari-hari secara mandiri. Intervensi self-management juga mempunyai pengaruh positif pada kemampuan bergerak, berkomunikasi dan meningkatkan proses pemulihan pasien stroke. Meningkatnya partisipasi selfmanagement melalui pemberdayaan akan membantu pasien mempelajari merawat diri sendiri. (Lee, Fischer, Zera, Robertson, \& Hammel ., 2017).

Partisipasi pasien secara aktif akan mempengaruhi self efficacy dalam manajemen penyakit, meningkatkan perilaku self-management dan pemulihan fungsi pasca stroke. Program selfmanagement meningkatkan activities of daily living (ADL) dan menurunkan readmisi pada pasien stroke serangan pertama (Chen et al ., 2018). Intervensi self-management berdampak positif dalam meningkatkan kemampuan pasien stroke memanajemen penyakitnya (Jones et al., 2016). Self-management juga dicatat mampu mempengaruhi fungsi dan partisipasi sosial dan direkomendasikan untuk pasien stroke.

Intervensi self-management dapat diberikan pada periode rawat inap, periode pemulangan dan pasca pemulangan. Periode rawat inap dapat dilakukan melalui penilaian yang berpusat pada pasien dan pendidikan self-management melalui sesi individu atau sesi kelompok. Sesi individu dapat diberikan selama 5 hari 20 menit setiap sesi setelah kondisi stabil dan sesi kelompok dapat diberikan pada minggu ke 2. Sesi kelompok dilakukan selama 60 menit per sesi dibagi menjadi 2 yaitu 20 menit dengan melihat video tentang self-management pasien stroke dan pengetahuan ketrampilan selfmanagement dan 40 menit edukasi tentang kemandirian serta pengembangan self- 
management termasuk berbagi pengalaman tentang self-management.

Pada periode pemulangan bertujuan untuk meningkatkan kesiapan pasien pada saat pemulangan dan periode pasca pemulangan bertujuan untuk menilai ketrampilan dan perilaku selfmanagement. Intervensi self-management juga dapat diberikan bersamaan dengan jadwal rehabilitasi rawat jalan dengan fasilitator perawat atau terapis. Kegiatan dilakukan secara kelompok dimana peserta bekerjasama dengan fasilitator untuk menetapkan tujuan pribadi dan perencanaan tindakan, kegiatan self efficacy untuk, menentukan kebutuhan kesehatan dengan sumber daya yang ada. Masing-masing peserta diberikan buku kerja self-management stroke untuk membantu pelaksanaan self-management di rumah.

Kegiatan kelompok dilakukan selama 6 minggu kemudian dilanjutkan kegiatan pasca pemulangan dengan follow up melalui telepon dapat dilakukan 2 minggu sekali selama 4 minggu. Fasilitator memberikan umpan balik positif langkah self-management, strategi pemecahan masalah, meningkatkan kepercayaan diri dan motivasi. Kegiatan tindak lanjut melalui telepon menggunakan menggunakan protokol atau standart prosedur operasional (SPO) tertentu.

Faktor pendukung yang memungkinkan keberhasilan selfmanagement meliputi: dukungan dari manajemen untuk terselenggaranya program self-management antara lain pelatihan terhadap perawat fasilitator, sarana dan prasarana yang mendukung, anggaran untuk melakukan follow up pasca pemulangan, buku kerja selfmanagement stroke, penyusunan materi edukasi dan SPO intervensi selfmanagement.

Faktor yang kemungkinan menghambat keberhasilan intervensi selfmanagement pasien stroke antara lain kesiapan pasien stroke untuk memberdayakan diri mereka karena fokus dari intervensi self-management adalah pemberdayaan. Selain itu dukungan keluarga sangat diperlukan karena keterlibatan keluarga mempunyai peran yang besar dalam keberhasilan selfmanagement. Faktor finansial diperlukan dalam melakukan implementasi seperti pelatihan program self-management (Jones, 2016).

\section{KESIMPULAN DAN SARAN}

Dari hasil pembahasan diatas dapat disimpulkan bahwa intervensi selfmanagement merupakan program yang membantu pasien stroke dalam beradaptasi dengan kondisi jangka panjang tanpa menyebabkan menurunnya kualitas hidup mereka. Intervensi selfmanagement merupakan salah satu upaya untuk mengurangi biaya yang ditimbulkan akibat pasien readmisi ke rumah sakit. Diharapkan program ini dapat diterapkan pada pasien stroke yang menjalani rawat inap maupun rawat jalan.

Program ini juga memungkinkan untuk diterapkan di Indonesia dengan beberapa catatan antara lain yaitu sumber daya manusia dipersiapkan untuk program self-management antara lain training untuk perawat sebagai fasilitator baik individu maupun kelompok pada intervensi stroke self-management, adanya biaya operasional yang mendukung terselenggaranya program self-management.

Biaya operasional meliputi anggaran biaya pelatihan untuk fasilitator stroke 
self-management, anggaran follow up pasca rawat inap (dengan telepon atau fasilitas whatsApp), anggaran materi edukasi dengan alat bantu dan buku kerja stroke self-management, adanya sarana dan fasilitas yang mendukung terselenggaranya program selfmanagement. Fasilitas yang dibutuhkan yaitu tempat terselenggaranya program intervensi self-management, video edukasi, buku kerja stroke selfmanagement, adanya dukungan dari pengambil kebijakan di setiap institusi pelayanan kesehatan dalam penerapan program self-management. Peran pengambil kebijakan meliputi penyusunan materi edukasi dan Standar Prosedur Operasional (SPO) intervensi selfmanagement dari pimpinan institusi.

\section{DAFTAR RUJUKAN}

Atler, K. E., Van Puymbroeck, M., Portz, J. D., \& Schmid, A. A. (2017). Participant-perceived outcomes of merging yoga and occupational therapy: Self-management intervention for people post stroke. British Journal of Occupational Therapy, 80(5), 294-301. https://doi.org/10.1177/0308022617 690536

Black, J., \& Hawks, H. J. (2014). Keperawatan Medikal bedah: manajemen klinis untuk hasil yang diharapkan (8th ed.). Singapore: Elsevier.

Ce, F., Ja, L., Mn, M.,\& Sl, H.(2016). Self management programmes for quality of life in people with stroke (Review) Summary of Findings For The Main Comparison,(8),12.https://doi.org/10.1002/14651858.
CD010442.pub2.www.cochranelibra ry.com

Chen, L., Chen, Y., Chen, X., Shen, X., Wang, Q., \& Sun, C. (2018). Longitudinal Study of Effectiveness of a Patient-Centered SelfManagement Empowerment Intervention During Predischarge Planning on Stroke Survivors. Worldviews on Evidence-Based Nursing, 15(3), 197-205. https://doi.org/10.1111/wvn.12295

Donkor, E. S. (2018). Stroke in the 21st Century: A Snapshot of the Burden, Epidemiology, and Quality of Life. Stroke Research and Treatment, 2018.

https://doi.org/10.1155/2018/323816 5

Fletcher, S., Kulnik, S. T., Demain, S., \& Jones, F. (2019). The problem with self-management: Problematising self-management and power using a Foucauldian lens in the context of stroke care and rehabilitation. PLoS ONE, 14(6), 1-21. https://doi.org/10.1371/journal.pone. 0218517

Guan, F. G., Wang, M., \& Lian, X. Q. (2018). The status quo and influence of self-management behaviors in convalescent stroke patients. Frontiers of Nursing, 5(2), 119-125. https://doi.org/10.2478/fon-20180016

Jones, F., Gage, H., Drummond, A., Bhalla, A., Grant, R., Lennon, S., ... Liston, M. (2016). Feasibility study of an integrated stroke selfmanagement programme: A cluster- 
randomised controlled trial. $B M J$ Open, $\quad 6(1)$, $1-10$. https://doi.org/10.1136/bmjopen2015-008900

Lee, D., Fischer, H., Zera, S., Robertson, R., \& Hammel, J. (2017). Examining a participation-focused stroke self-management intervention in a day rehabilitation setting: A quasi-experimental pilot study. Topics in Stroke Rehabilitation, 24(8), 601-607. https://doi.org/10.1080/10749357.20 17.1375222

Mozaffarian, D., Benjamin, E. J., Go, A. S., Arnett, D. K., Blaha, M. J., Cushman, M., ... Turner, M. B. (2016). Heart Disease and Stroke Statistics-2016 Update. Circulation (Vol. 133). https://doi.org/10.1161/cir.00000000 00000350

Pearce, G., Pinnock, H., Epiphaniou, E., Parke, H. L., Heavey, E., Griffiths, C. J., ... Taylor, S. J. C. (2015). Experiences of self-management support following a stroke: A metareview of qualitative systematic reviews. PLOS ONE, 10(12), 1-17. https://doi.org/10.1371/journal.pone. 0141803

Rahmawati, D., Kurniawan, T., \& Hartati, S. (2018). Gambaran SelfManagement pada Pasien Stroke yang Menjalani Rawat Jalan, 6(Imd), 18-29.

Rutherford, S. J., Hocking, C., Theadom, A., \& McPherson, K. M. (2018). Exploring challenges at 6 months after stroke: What is important to patients for self-management? International Journal of Therapy and Rehabilitation, 25(11), 565575.

https://doi.org/10.12968/ijtr.2018.25 .11 .565

Sit, J. W. H., Chair, S. Y., Choi, K. C., Chan, C. W. H., Lee, D. T. F., Chan, A. W. K., ... Taylor-Piliae, R. E. (2016). Do empowered stroke patients perform better at selfmanagement and functional recovery after a stroke? A randomized controlled trial. Clinical Interventions in Aging, 11, 14411450.

https://doi.org/10.2147/CIA.S10956 0

Wolf, T. J., Spiers, M. J., Doherty, M., \& Leary, E. V. (2017). The effect of self-management education following mild stroke: An exploratory randomized controlled trial*. Topics in Stroke Rehabilitation, 24(5), 345-352. https://doi.org/10.1080/10749357.20 17.1289687 